\title{
Studi Eksperimental Unjuk Kerja Motor Diesel Putaran Stasioner dengan Campuran Bahan Bakar Biodiesel Buah Nyamplung
}

\author{
Yuliyanti Dian Pratiwi ${ }^{1}$, Sutarno $^{2}$, Warso ${ }^{3}$ \\ ${ }^{1,2,3}$ Program Studi Teknik Mesin Sekolah Tinggi Teknik Wiworotomo Purwokerto \\ e-mail : ${ }^{1}$ dianhilal@gmail.com, ${ }^{2}$ sutarnopas@gmail.com, ${ }^{3}$ warso.januari@gmail.com
}

\begin{abstract}
ABSTRAK
Berkembangnya teknologi pada zaman ini dan pola kehidupan manusia yang terus mengalami perkembangan mengakibatkan kebutuhan energi semakin meningkat, sehingga ketersediaan energi bahan bakar fosil yang tidak dapat diperbarui semakin menipis, bahkan diperkirakan semakin lama akan habis. Produk salah satu sumber minyak nabati yang sangat prospektif untuk dimanfaatkan sebagai bahan baku biodiesel adalah hasil dari proses pengolahan biji nyamplung (Calophyllum Inophyllum L). Hal ini disebabkan karena minyak biji nyamplung tidak termasuk dalam kategori kebutuhan pangan, sehingga pemanfaatannya sebagai biodiesel tidak akan mengganggu dalam kebutuhan pangan manusia. Tujuan penelitian ini menetahui seberapa torsi dan daya serta sfc terhadap campuran bahan bakar biodesel buah nyamplung. penelitian ini menggunakan studi eksperimental dengan penelitian yang telah dilakukan menghasilkan daya, torsi, dan sfc dari campuran $20 \%$ sebesar $1,72 \mathrm{~kW}, 10,955 \mathrm{~N}$.m dan nilai naik/turun 10,08\%. Presentase 30\% 1,692kW, 10,777N.m dan nilai naik/turun $-1,09 \%$. Presentase $40 \%$ 1,719kW, 10,949N.m dan nilai naik/turun 5,77\% untuk dexlite. Presentase $20 \%$ 1,722kW, 10,968N.m dan nilai naik/turun 4,63\%. Presentase 30\% 1,710kW, 10,891N.m dan nilai naik/turun 6,52\%. Presentase 40\% 1,722kW, 10,968N.m dan nilai naik 5,95\% untuk Pertamina DEX.
\end{abstract}

Kata Kunci : Motor Diesel, Minyak Nyamplung, torsi,daya ,Sfc

\section{ABSTRACT}

The recent development of technology and the continuous development of human lifestyle have resulted in the increasing of the need for energy, so that the availability of energy from non-renewable fossil fuels is decreasing, and it is even predicted that it will run out over time. One of the most prospective vegetable oil resources to be used as a raw material for biodiesel is product from the processing of nyamplung seeds (Calophyllum Inophyllum L). Due to nyamplung seed oil is not included in the category of primary food needs, so its usage as a biodiesel will not interfere with human food needs. The purpose of this research is to find out how much torque and sfc power to the mixture of biodiesel fuel from nyamplung fruit. This research used experimental studies with research that has been done to produce Power, Torque, and Sfc from a mixture of $20 \%$ of $1.72 \mathrm{~kW}, 10,955 \mathrm{Nm}$ and the value of increase down $10.08 \%$. Percentage of $30 \% 1,692 \mathrm{~kW}$, $10,777 \mathrm{~N} . \mathrm{m}$ and the value increase / decrease $-1.09 \%$. The percentage of $40 \% 1,719 \mathrm{~kW}, 10,949 \mathrm{~N} . \mathrm{m}$ and the rate is up / down $5.77 \%$ for Dexlite. Percentage of $20 \%$ 1,722kW, 10,968N.m and 4.63\% increase / decrease value. Percentage of $30 \%$ $1,710 \mathrm{~kW}, 10,891 \mathrm{~N} . \mathrm{m}$ and value increase / decrease $6.52 \%$. The percentage of $40 \% 1,722 \mathrm{~kW}, 10,968 \mathrm{~N} . \mathrm{m}$ and the increased value by $5.95 \%$ for Pertamina DEX.

Keywords : Diesel Motor, Nyamplung Oil, Motor Performance

\section{Pendahuluan}

Seiring dengan berkembangnya pada zaman ini dan pola kehidupan manusia yang terus mengalami perkembangan mengakibatkan kebutuhan energi semakin meningkat, serta kebutuhan sarana transportasi dan aktivitas industri yang berakibat pada peningkatan kebutuhan khususnya pada konsumsi Bahan Bakar Minyak (BBM). Indonesia akan terancam mengalami krisis energi dalam beberapa tahun mendatang. Penyebabnya adalah terjadi kesenjangan antara permintaan energi yang tinggi dan pasokan produksi minyak di dalam negeri. Di lain pihak persediaan minyak dunia diperkirakan akan habis dalam kurun waktu 36,5 tahun terhitung sejak 2002 [1][2]

Kemungkinan juga Indonesia akan mengalami hal yang sama dengan cadangan minyak hanya cukup untuk memenuhi konsumsi selama 18 tahun mendatang. Oleh sebab itu, penggunaan energi yang berbasis bahan bakar asal fosil perlu dikurangi dengan cara mengoptimalkan penggunaan energi yang terbarukan dan mengurangi 
subsidi bahan bakar minyak. Indonesia memiliki banyak sumber daya alam hayati yang dapat dimanfaatkan sebagai bahan baku bioenergi (biodiesel) [3]. Di Indonesia minyak solar merupakan bahan bakar yang sering digunakan, namun untuk menekan tingkat penggunaan bahan bakar tersebut dengan penggantian ke biodesel [4]. Pemilihan biodiesel saat ini memang keputusan tepat karena jenis alkohol yang dihasilkan adalah metanol, metanol disini merupakan turunan dari alkohol sehingga kebutuhan untuk proses alkoholisis tidak banyak, murah dan stabil. Kemudian unsur reaksi kimianya jauh lebih tinggi dibandingkan unsur etanol [5]

Dari beberapa bahan baku di Indonesia yang mempunyai prospek untuk diolah menjadi biodiesel adalah biji nyamplung karena biji nyamplung ini tidak berhubungan dengan kebutuhan pangan manusia, sehingga dapat dimanfaatkan secara optimal. Sebagai salah satu sumber energi alternatif, biodiesel dari tanaman nyamplung dikategorikan sebagai sumber energi ramah lingkungan [6]. Pembakaran pada motor yang berbahan bakar biodiesel menghasilkan emisi gas buang, asap dan partikel yang lebih rendah. Angka cetana yang lebih tinggi dibandingkan dengan solar membuat kadar emisi gas karbon, nitrogen, dan sulfur lebih rendah. Biodiesel merupakan suatu nama dari alkyl ester atau rantai panjang asam lemak yang berasal dari minyak nabati maupun minyak hewani. Komponen utama dari minyak nabati maupun lemak hewani adalah Triacylglycerols (TAG), sering juga disebut Triglycerides. Salah satu bahan bakar nabati yang berasal dari tanaman dan penelitiannya sudah mulai berkembang serta populasinya tersebar hampir di seluruh pantai berpasir di Indonesia adalah tanaman nyamplung (Calophyllum Inophyllum) yang mempunyai rendemen hampir $73 \%$ [7].

Upaya pengolahan biji nyamplung menjadi biodiesel dan pemanfaatan hasil ikutannya perlu dilakukan karena terkait dengan kebijakan pembangunan pemerintah dalam hal diversifikasi energi baru dan terbarukan (renewable energy), menghasilkan teknologi tepat guna untuk memenuhi kebutuhan energi lokal sehingga dapat mengurangi pemakaian bahan bakar yang berasal dari minyak bumi. Pembuatan biodiesel yang berbahan baku dari biji nyamplung ini sangat berguana untuk menjalankan motor diesel seperti: mesin diesel kendaraan pribadi, mesin diesel kendaraan umum, dan mesin diesel generator/genset. Tetapi ada kendala pada biodiesel ini salah satu contohnya adalah viskositas pada biodiesel tersebut masih tinggi sehingga aliran dari tangki bahan bakar menuju pompa injeksi tidak sempurna.

Penelitian ini melakukan analisis tentang Daya, Torsi dan Spesific Fuel Consumtion (Sfc) yang menggunakan motor diesel 4 Langkah atau Diesel Generator Set. Dan bahan bakar Minyak Nyamplung tersebut dicampurkan pada solar murni dengan presentase $\mathrm{BN} 20 \%$, BN 30\%, dan BN $40 \%$ yang akan diumpankan dalam motor diesel tersebut.

Penelitian ini bertujuan untuk menganalisa prestasi kerja Daya, Torsi, dan Spesific Fuel Consumtion (Sfc) pada penggunaan bahan bakar Dexlite 100\%, BN 20\%, BN 30\%, BN 40\% dan menganalisa prestasi kerja Daya, Torsi dan Spesific Fuel Consumtion (Sfc) pada penggunaan bahan bakar Pertamina DEX 100\%, BN $20 \%$, BN $30 \%$, BN $40 \%$.

Tujuan penelitian ini diharapkan dapat mengetahui torsi ,daya dan sfc terhadap penggunaan bahan bakar campuran Biodiesel Minyak Nyamplung yang di menggunakan motor diesel generator set dan menambah pengetahuan tentang bahan bakar Biodiesel, yang pada bahan dasarnya tidak hanya diperoleh dari lemak nabati ada juga Biodiesel yang bahan dasarnya terbuat dari lemak hewani.

\section{Tinjauan Pustaka}

Proses ini terjadi pada motor diesel 4 langkah dengan putaran rendah. Pada motor diesel yang dihisap bukan campuran udara dan bahan bakar, melainkan hanya udara saja. Sesaat sebelum akhir kompresi, bahan bakar disemprotkan dalam bentuk kabut ke dalam silinder. Bahan bakar ini terbakar karena suhu udara yang tinggi. Suhu udara yang tinggi diperoleh karena adanya kompresi adiabatik. Ketika bahan bakar disemprotkan memperoleh suhu yang tinggi dari titik nyala bahan bakar tersebut. Agar bahan bakar dan udara dapat bercampur secara homogen, maka gerakan udara di dalam silinder harus merupakan aliran turbulen. Pembakarannya terjadi pada tekanan tetap [8].
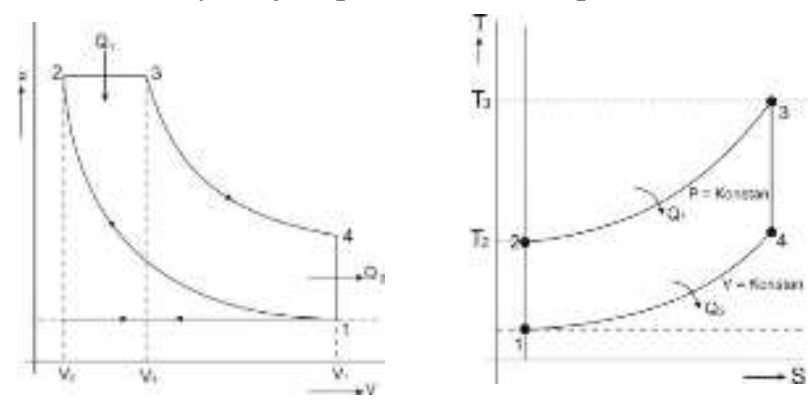

Gambar.1 Diagram P-V dan T-S

Minyak nabati sebagai sumber utama biodiesel dapat dipenuhi dari berbagai macam jenis tumbuhan tergantung pada sumber daya utama yang banyak terdapat di suatu negara. Di Indonesia memiliki banyak sumber daya untuk bahan baku biodiesel seperti ditunjukkan pada Tabel dibawah ini Sumber minyak nabati dikatakan potensial sebab mudah untuk dibudidayakan, sedangkan sumber minyak nabati dikatakan non potensial karena sulit untuk dibudidayakan. Berikut adalah sumber yang ada di Indonesia: 
Tabel 1. Beberapa sumber minyak nabati yang potensial sebagai bahan baku Biodiesel

\begin{tabular}{|c|c|c|c|c|}
\hline Nama Lokal & Nama Latin & $\begin{array}{l}\text { Sumber } \\
\text { Minyak }\end{array}$ & $\begin{array}{c}\text { Isi \% } \\
\text { Berat } \\
\text { kering }\end{array}$ & $\begin{array}{l}\mathbf{P} / \\
\mathbf{N P}\end{array}$ \\
\hline Jarak Pagar & Jatropa Curcas & Inti biji & $40-60$ & $\mathrm{P}$ \\
\hline Jarak kaliki & $\begin{array}{c}\text { Riccinus } \\
\text { Communis }\end{array}$ & Biji & $45-50$ & $\mathrm{P}$ \\
\hline Kacang Suuk & Arachis Hypogea & Biji & $35-55$ & $\mathrm{P}$ \\
\hline $\begin{array}{c}\text { Kapok / } \\
\text { Randu }\end{array}$ & Ceiba Pantandra & Biji & $24-40$ & NP \\
\hline Karet & Hevea Brasiliensis & Biji & $40-50$ & $\mathrm{P}$ \\
\hline Kecipir & $\begin{array}{c}\text { Psophocarpus } \\
\text { Tetrag }\end{array}$ & Biji & $15-20$ & $P$ \\
\hline Kelapa & Cocos Nucifera & Inti Biji & $60-70$ & $\mathrm{P}$ \\
\hline Kelor & Moringa Oliefera & Biji & $30-49$ & $\mathrm{P}$ \\
\hline Kemiri & $\begin{array}{l}\text { Aleurites } \\
\text { moluccana }\end{array}$ & Inti Biji & $57-69$ & NP \\
\hline Kusambi & Sleichera Trijuga & Sabut & $55-70$ & NP \\
\hline Nimba & $\begin{array}{l}\text { Azadiruchta } \\
\text { Indica }\end{array}$ & Inti Biji & $40-50$ & NP \\
\hline Saga Utan & $\begin{array}{c}\text { Adenanthera } \\
\text { pavonina }\end{array}$ & Inti Biji & $14-28$ & $\mathrm{P}$ \\
\hline Sawit & Elais Suincecis & $\begin{array}{c}\text { Sabut } \\
\text { dan Biji }\end{array}$ & $\begin{array}{c}45-70+ \\
46-54\end{array}$ & $\mathrm{P}$ \\
\hline Nyamplung & $\begin{array}{l}\text { Callophyllum } \\
\text { Lanceatum }\end{array}$ & Inti Biji & $40-73$ & $P$ \\
\hline Randu Alas & $\begin{array}{c}\text { Bombax } \\
\text { Malabaricum }\end{array}$ & Biji & $18-26$ & NP \\
\hline Sirsak & Annona Muricata & Inti Biji & $20-30$ & NP \\
\hline Sirkaya & Annona Squosa & Biji & $15-20$ & NP \\
\hline
\end{tabular}

\section{Metedologi Penelitian}

Pada penelitian ini metode yang digunakan adalah penelitian eksperimental untuk mengetahui tentang kualitas bahan bakar Dexlite, dan Pertamina DEX dengan pencampuran Biodiesel minyak biji Nyamplung $20 \%, 30 \%$ dan $40 \%$ terhadap daya, torsi, serta $s f c$.

\subsection{Alat}

a. Panel pembebanan lampu

Digunakan sebagai pembebanan pada motor diesel yaitu daya yang keluar dari motor diesel di konversikan oleh generator menjadi listrik menuju ke panel pembebanan lampu.

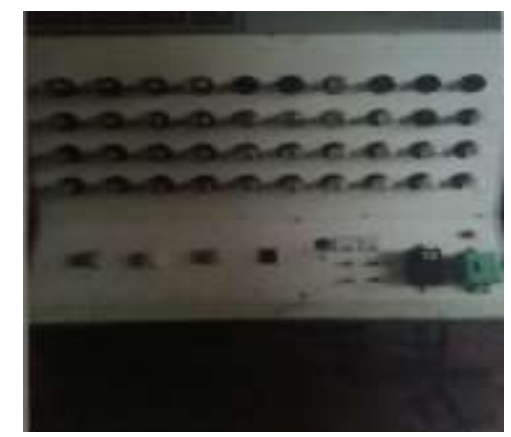

Gambar 2. Panel Pembebanan Lampu

\section{b. Burret}

Berfungsi untuk mengetahui jumlah volume bahan bakar yang akan dipakai dalam penelitian/percobaan pada bahan bakar dengan satuan ukuran (ml)

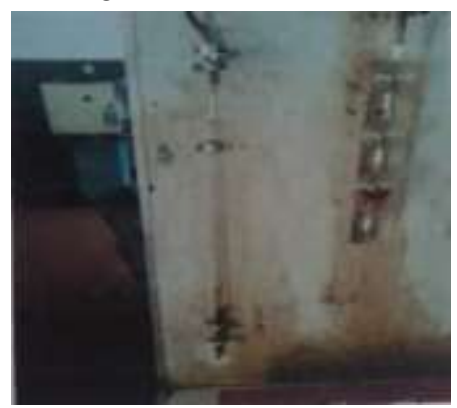

Gambar 3. Burret

c. Power Analyzer

Berfungsi untuk mengukur besarnya daya listrik, tegangan, arus listrik, frekuensi dan power factor (faktor kerja).

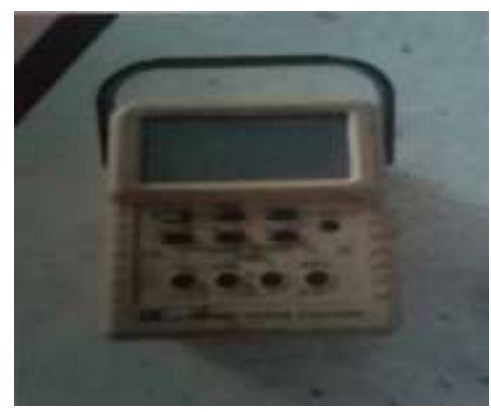

Gambar 4. Power Analyzer

d. Stopwatch

Berfungsi untuk mengukur waktu lamanya pengosongan burret diukur dari 10ml hingga $0 \mathrm{ml}$ yang telah diisi bahan bakar.

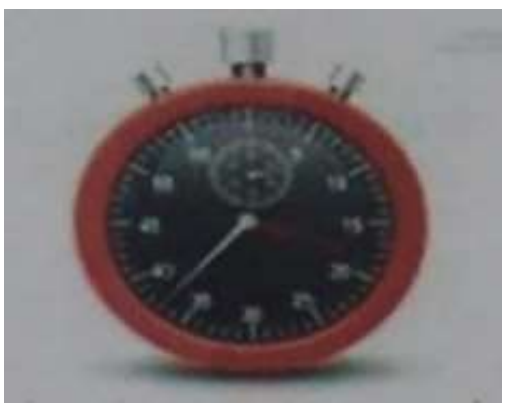

Gambar 5. Stopwatch

e. Tool kit

Terdiri dari satu set kunci ring dan kunci pas, obeng, tang, dan kunci inggris. Alat tersebut digunakan untuk memperbaiki dan men tune-up motor diesel tersebut jika terjadi trouble pada mesin tersebut. 


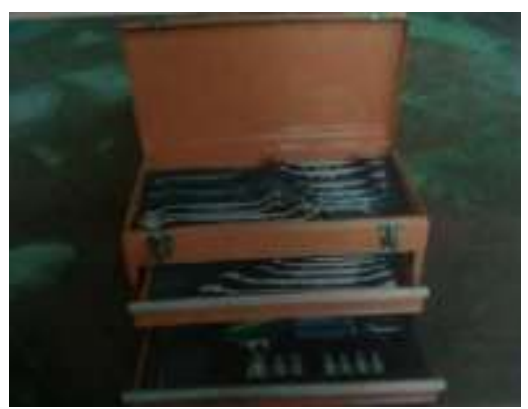

Gambar 6. Tool Kit

\subsection{Bahan}

a. Motor Diesel stasioner yang akan digunakan untuk penelitian dengan spesifikasi sebagai berikut; Model R180 ; Type 1 silinder berpendingin air 4Langkah ; Diameter silinder 80mm ; Piston Stroke 80mm ; Perbandingan Kompresi 21:1.

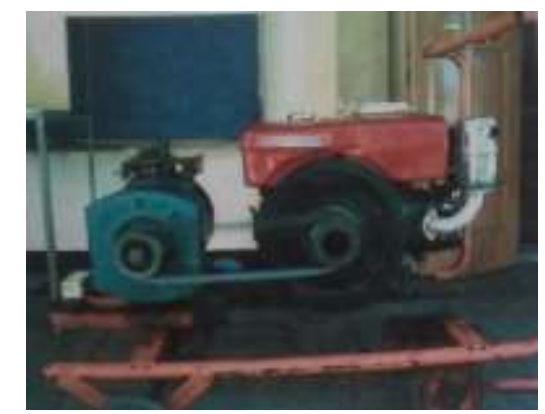

Gambar 7. Motor Diesel Generator set

b. Generator set dengan spesifikasi; Merk HuaFa ; Power 3KW ; Voltase 230V ; Arus 13 A ; Frekuensi 50Hz; Putaran 1500rpm.

c. Minyak biji Nyamplung yang diperoleh dari Bpk.Sumino beralamat di desa Karangmangu, Kecamatan Kroya, Kabupaten Cilacap, Jawa Tengah.

d. Bahan Bakar Minyak (BBM), yang digunakan adalah Dexlite, dan Pertamina DEX.

\subsection{Flowchat penelitian}

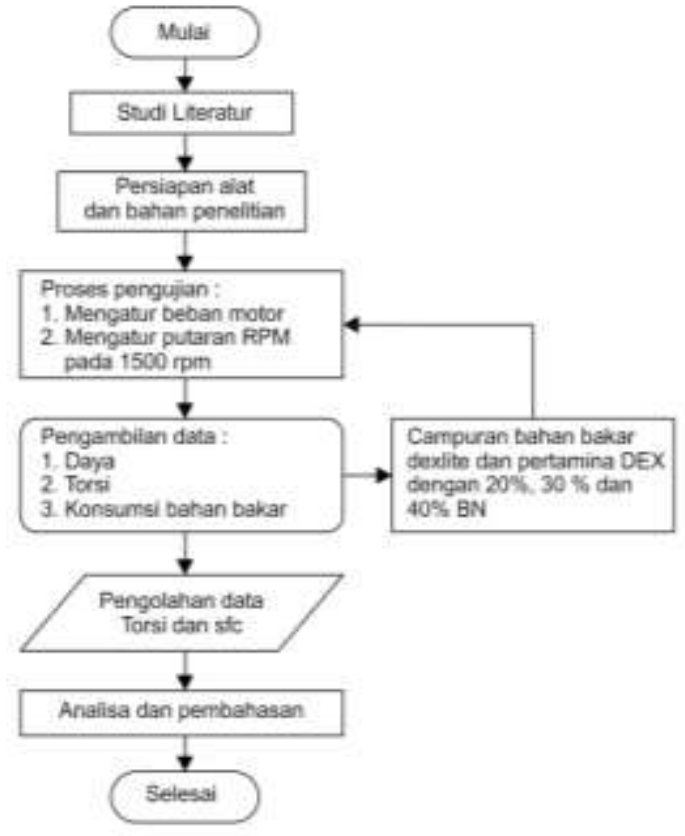

Gambar 8. Flowchat penelitian

\section{Analisa dan Pembahasan}

Hasil dari data yang diperoleh akan dihitung untuk menemukan parameter yang akan dicari untuk mengetahui seberapa besar prestasi kerja motor diesel yang dihasilkan. Setelah mengetahui data yang telah dihasilkan akan dibuat grafik untuk perbandingan satu variabel dengan variabel yang lainnya, guna untuk menentukan prestasi kerja yang lebih baik dari variabel yang lainnya.

\subsection{Analisa Daya (Dexlite)}

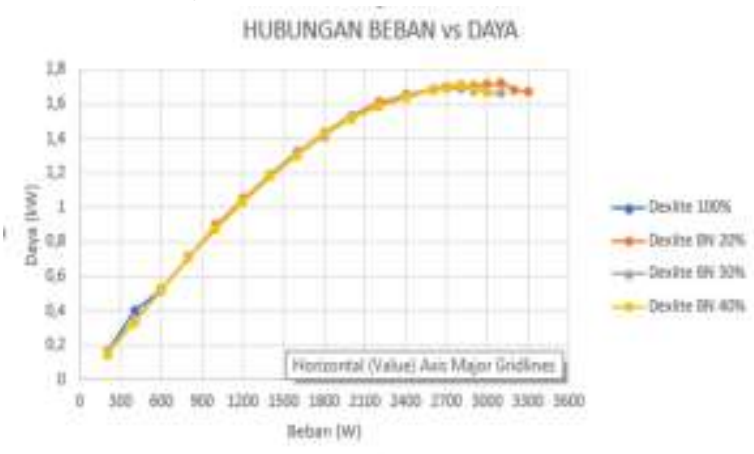

Gambar 9. Grafik Hubungan antara Beban vs Daya

Dari hasil perhitungan untuk grafik beban vs daya menunjukkan bahwa semakin besar penambahan beban pada motor, maka Daya yang dihasilkan juga akan semakin bertambah besar. Hal ini terbukti pada tabel diatas mulai dari beban 200watt sampai 2800watt Daya yang dihasilkan mulai dari $0,160 \mathrm{~kW}$ samapai $1,707 \mathrm{~kW}$ untuk Dexlite $100 \%$, kemudian pada penambahan beban 2900watt terjadi penurunan Daya. Sedangkan beban mulai dari 200watt sampai 3100watt Daya yang dihasilkan mulai dari $0,147 \mathrm{~kW}$ sampai $1,720 \mathrm{~kW}$ untuk Dexlite BN 20\%, kemudian pada penambahan beban 3200 watt terjadi penurunan Daya. Sedangkan beban 
mulai dari 200watt sampai 2900watt Daya yang dihasilkan mulai dari $0,158 \mathrm{~kW}$ sampai $1,692 \mathrm{~kW}$ untuk Dexlite BN 30\%, kemudian pada penambahan beban 3000watt terjadi penurunan Daya. Sedangkan beban mulai dari 200watt sampai 2800watt Daya yang dihasilkan mulai dari $0,156 \mathrm{~kW}$ sampai $1,719 \mathrm{~kW}$ untuk Dexlite BN $40 \%$, kemudian pada penambahan beban 2900 watt terjadi penurunan Daya.

\subsection{Analisa Torsi (Dexlite)}

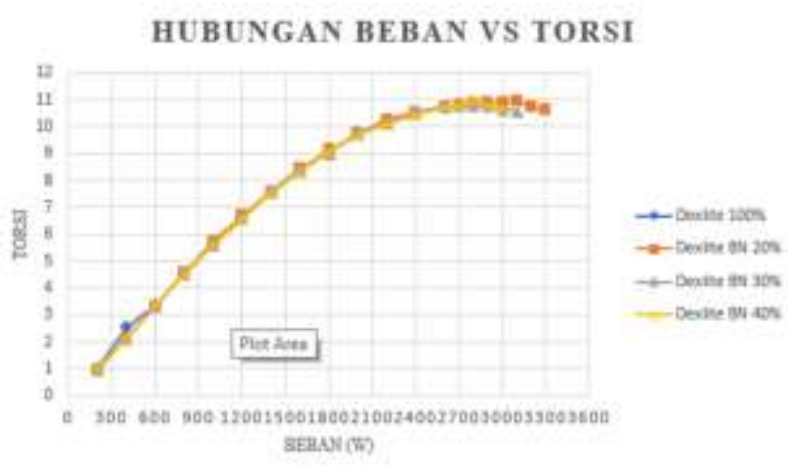

Gambar 10. Grafik Hubungan antara Beban vs Torsi

Dari hasil perhitungan untuk grafik beban vs Torsi menunjukkan bahwa semakin besar penambahan beban pada motor, maka Torsi yang dihasilkan juga akan semakin bertambah besar. Hal ini terbukti pada tabel diatas mulai dari beban 200watt sampai 2800watt Torsi yang dihasilkan mulai dari 1,019N.m samapai 10,872N.m untuk Dexlite 100\%, kemudian pada penambahan beban 2900watt terjadi penurunan Torsi. Sedangkan beban mulai dari 200watt sampai 3100watt Torsi yang dihasilkan mulai dari 0,936N.m sampai 10,955N.m untuk Dexlite BN 20\%, kemudian pada penambahan beban 3200watt terjadi penurunan Torsi. Sedangkan beban mulai dari 200watt sampai 2900watt Torsi yang dihasilkan mulai dari 1,006N.m sampai 10,777N.m untuk Dexlite BN 30\%, kemudian pada penambahan beban 3000watt terjadi penurunan Torsi. Sedangkan beban mulai dari 200watt sampai 2800watt Torsi yang dihasilkan mulai dari 0,993N.m sampai 10,949N.m untuk Dexlite BN 40\%, kemudian pada penambahan beban 2900 watt terjadi penurunan Torsi.

\subsection{Analisa Spesific Fuel Consumtion (Dexlite) HUBUNGAN BEBAN VS $S F C$}

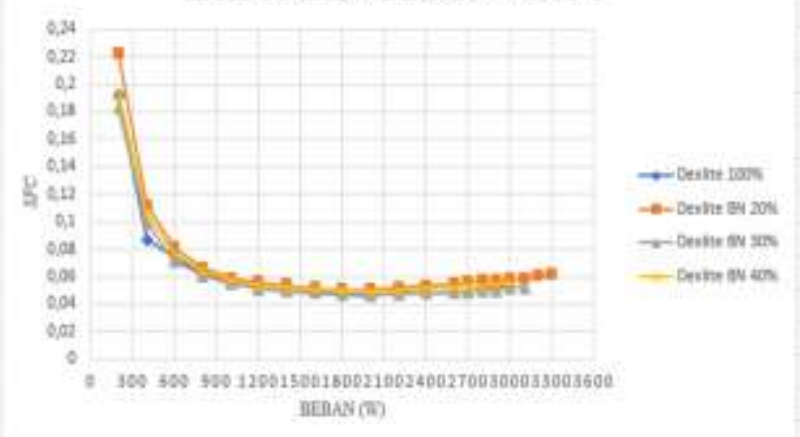

Gambar 11. Grafik Hubungan antara Beban vs $S f c$

Dari hasil perhitungan untuk grafik beban vs $S f c$ menunjukkan bahwa semakin besar penambahan beban pada motor, maka bahan bakar yang dibutuhkan pada motor diesel tersebut bervariasi. Hal ini terbukti pada tabel diatas mulai dari beban 200watt sampai 2000watt Sfc yang dihasilkan mulai dari $0,191 \mathrm{Kg} / \mathrm{kWh}$ samapai $0,049 \mathrm{Kg} / \mathrm{kWh}$ untuk Dexlite $100 \%$, kemudian pada penambahan beban 2200watt terjadi kenaikan Sfc pada motor tersebut. Sedangkan beban mulai dari 200watt sampai 2000watt Sfc yang dihasilkan mulai dari $0,222 \mathrm{Kg} / \mathrm{kWh}$ sampai $0,050 \mathrm{Kg} / \mathrm{kWh}$ untuk Dexlite BN $20 \%$, kemudian pada penambahan beban 2200watt terjadi kenaikan $S f c$ pada motor tersebut. Sedangkan beban mulai dari 200watt sampai 2000watt Sfc yang dihasilkan mulai dari $0,182 \mathrm{Kg} / \mathrm{kWh}$ sampai $0,046 \mathrm{Kg} / \mathrm{kWh}$ untuk Dexlite BN 30\%, kemudian pada penambahan beban 2200watt terjadi kenaikan Sfc pada motor tersebut. Sedangkan beban mulai dari 200watt sampai 2000watt Sfc yang dihasilkan mulai dari $0,193 \mathrm{Kg} / \mathrm{kWh}$ sampai $0,049 \mathrm{Kg} / \mathrm{kWh}$ untuk Dexlite BN $40 \%$, kemudian pada penambahan beban 2200watt terjadi kenaikan $S f c$ pada motor tersebut.

\subsection{Analisa Daya (Pertamina DEX)}

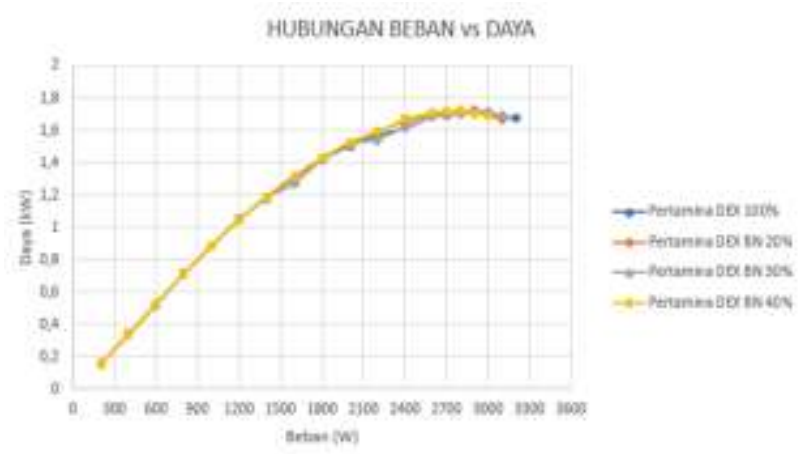

Gambar 12. Grafik Hubungan antara Beban vs Daya

Dari hasil perhitungan untuk grafik beban vs Daya menunjukkan bahwa semakin besar penambahan beban pada motor, maka Daya yang dihasilkan juga akan semakin bertambah besar. Hal ini terbukti pada tabel diatas mulai dari beban 200watt sampai 3000watt Daya 
yang dihasilkan mulai dari $0,156 \mathrm{~kW}$ samapai $1,712 \mathrm{~kW}$ untuk Pertamina DEX 100\%, kemudian pada penambahan beban 3100watt terjadi penurunan Daya. Sedangkan beban mulai dari 200watt sampai 2900watt Daya yang dihasilkan mulai dari $0,160 \mathrm{~kW}$ sampai $1,722 \mathrm{~kW}$ untuk Pertamina DEX BN 20\%, kemudian pada penambahan beban 3000 watt terjadi penurunan Daya. Sedangkan beban mulai dari 200watt sampai 2900watt Daya yang dihasilkan mulai dari $0,156 \mathrm{~kW}$ sampai $1,710 \mathrm{~kW}$ untuk Pertamina DEX BN 30\%, kemudian pada penambahan beban 3000watt terjadi penurunan Daya. Sedangkan beban mulai dari 200watt sampai 2800watt Daya yang dihasilkan mulai dari $0,155 \mathrm{~kW}$ sampai $1,722 \mathrm{~kW}$ untuk Pertamina DEX BN $40 \%$, kemudian pada penambahan beban 2900watt terjadi penurunan Daya.

\subsection{Analisa Torsi (Pertamina DEX)}

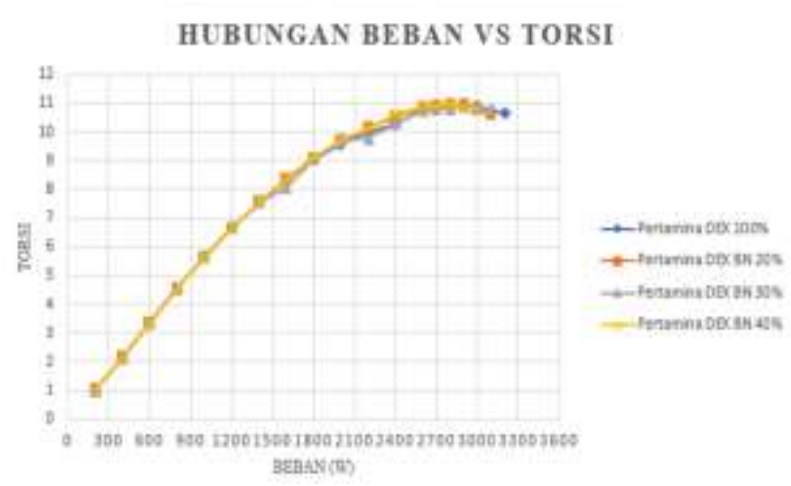

Gambar 13. Grafik Hubungan antara Beban vs Torsi

Dari hasil perhitungan untuk grafik beban vs Torsi menunjukkan bahwa semakin besar penambahan beban pada motor, maka Torsi yang dihasilkan juga akan semakin bertambah besar. Hal ini terbukti pada tabel diatas mulai dari beban 200 watt sampai 3000 watt Torsi yang dihasilkan mulai dari 0,993 N.m sampai 10,904 N.m untuk Pertamina DEX 100\%, kemudian pada penambahan beban 3100 watt terjadi penurunan Torsi. Sedangkan beban mulai dari 200 watt sampai 2900 watt Torsi yang dihasilkan mulai dari 1,019 N.m sampai 10,968 N.m untuk Pertamina DEX BN 20\%, kemudian pada penambahan beban 3000 watt terjadi penurunan Torsi. Sedangkan beban mulai dari 200 watt sampai 2900 watt Torsi yang dihasilkan mulai dari 0,993 N.m sampai 10,891 N.m untuk Pertamina DEX BN 30\%, kemudian pada penambahan beban 3000 watt terjadi penurunan Torsi. Sedangkan beban mulai dari 200 watt sampai 2800 watt Torsi yang dihasilkan mulai dari 0,987 N.m sampai 10,968 N.m untuk Pertamina DEX BN 40\%, kemudian pada penambahan beban 2900 watt terjadi penurunan Torsi.

\subsection{Analisa Spesific Fuel Consumtion (Pertamina DEX)}

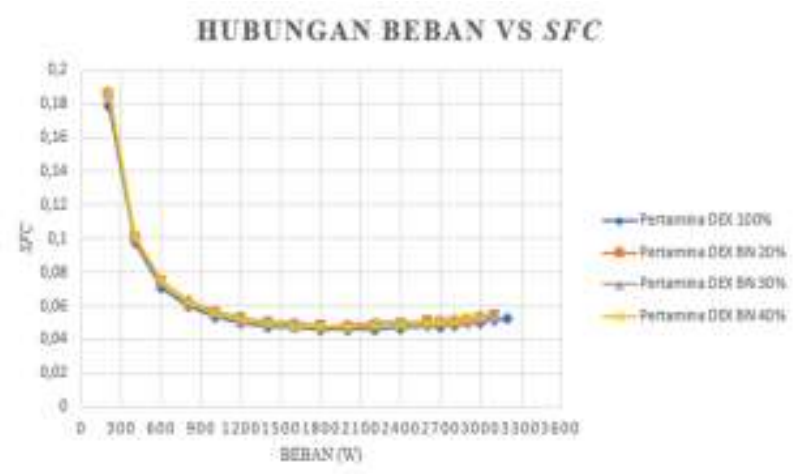

Gambar 13. Grafik Hubungan antara Beban vs $S f c$

Dari hasil perhitungan untuk grafik beban vs $S f c$ menunjukkan bahwa semakin besar penambahan beban pada motor, maka bahan bakar yang dibutuhkan pada motor diesel tersebut bervariasi. Hal ini terbukti pada tabel diatas mulai dari beban 200 watt sampai 1800 watt Sfc yang dihasilkan mulai dari $0,178 \mathrm{Kg} / \mathrm{kWh}$ sampai $0,045 \mathrm{Kg} / \mathrm{kWh}$ untuk Pertamina DEX 100\%, kemudian pada penambahan beban 2000 watt terjadi kenaikan $S f c$ pada motor tersebut. Sedangkan beban mulai dari 200 watt sampai 2000 watt $S f c$ yang dihasilkan mulai dari $0,185 \mathrm{Kg} / \mathrm{kWh}$ sampai $0,047 \mathrm{Kg} / \mathrm{kWh}$ untuk Pertamina DEX BN 20\%, kemudian pada penambahan beban 2200 watt terjadi kenaikan $S f c$ pada motor tersebut. Sedangkan beban mulai dari 200 watt sampai 2000 watt Sfc yang dihasilkan mulai dari $0,187 \mathrm{Kg} / \mathrm{kWh}$ sampai 0,048 $\mathrm{Kg} / \mathrm{kWh}$ untuk Pertamina DEX BN 30\%, kemudian pada penambahan beban 2200 watt terjadi kenaikan $S f c$ pada motor tersebut. Sedangkan beban mulai dari 200 watt sampai 2000 watt $S f c$ yang dihasilkan mulai dari 0,186 $\mathrm{Kg} / \mathrm{kWh}$ sampai $0,047 \mathrm{Kg} / \mathrm{kWh}$ untuk Dexlite BN 40\%, kemudian pada penambahan beban 2200 watt terjadi kenaikan $S f c$ pada motor tersebut.

\section{Kesimpulan}

Berdasarkan hasil penelitian yang telah dilakukan pada penggunaan bahan bakar Dexlite $100 \%$, BN 20\%, BN $30 \%$, dan BN $40 \%$ pada variabel berikut yang menghasilkan prestasi kerja yang paling baik adalah BN $20 \%$ dengan beban maksimal 3100watt menghasilkan Daya sebesar $1,72 \mathrm{~kW}$. Sedangkan, pada penggunaan bahan bakar Pertamina DEX 100\%, BN 20\%, BN 30\%, dan BN $40 \%$ pada variabel tersebut yang menghasilkan prestasi kerja yang paling baik adalah Pertamina DEX 100\% dengan beban maksimal 3000 watt menghasilkan Daya sebesar $1,712 \mathrm{~kW}$.

Dari hasil penelitian yang telah dilakukan pada penggunaan bahan bakar Dexlite 100\%, BN 20\%, BN $30 \%$, dan BN $40 \%$ pada variabel tersebut yang menghasilkan prestasi kerja yang paling baik adalah BN $20 \%$ dengan beban maksimal 3100 watt menghasilkan Torsi sebesar 10,955 N.m. Sedangkan, pada penggunaan 
bahan bakar Pertamina DEX 100\%, BN 20\%, BN 30\%, dan $\mathrm{BN} 40 \%$ pada variabel tersebut yang menghasilkan prestasi kerja yang paling baik adalah Pertamina DEX 100\% dengan beban maksimal 3000 watt menghasilkan Torsi sebesar 10,904 N.m.

Dari hasil penelitian yang telah dilakukan pada pengguanaan bahan bakar Dexlite $100 \%$, BN 20\%, BN $30 \%$, BN $40 \%$ dan pada penggunaan bahan bakar Pertamina DEX 100\% BN 20\%, BN 30\%, BN 40\% pada setiap variabel yang dipakai mengalami peningkatan prestasi kerja khususnya pada konsumsi bahan bakarnya menjadi lebih irit.

\section{Daftar Pustaka}

[1] Feby Dasa Eka Putri, "Krisis Minyak Tahun 1973-1974 di Negara-Negara Industri sebagai Penggerak Tata Ekonomi Dunia Baru," Avatara, vol. 2, no. 1, pp. 42-57, 2014.

[2] G. Prateepchaikul, M. L. Allen, T. Leevijit, and K. Thaveesinsopha, "Methyl ester production from high free fatty acid mixed crude palm oil," Songklanakarin J. Sci. Technol., vol. 29, no. 6, pp. 1551-1561, 2007.

[3] Wendi, Valentinoh Cuaca, and Taslim, "Pengaruh Suhu Reaksi dan Jumlah Katalis pada Pembuatan Biodiesel dari Limbah Lemak Sapi dengan Menggunakan Katalis Heterogen Cao dari Kulit Telur Ayam," J. Tek. Kim. USU, vol. 4, no. 1, pp. 35-41, 2015, doi: 10.32734/jtk.v4i1.1458.

[4] P. Padil, S. Wahyuningsih, and A. Awaluddin, "Pembuatan Biodiesel dari Minyak Kelapa melalui Reaksi Metanolisis Menggunakan Katalis $\mathrm{CaCO} 3$ yang dipijarkan," J. Natur Indones., vol. 13, no. 1, p. 27, 2012, doi: 10.31258/jnat.13.1.27-32.

[5] R. H. dan M. N. Rama Prihandana, Menghasilkan Biodiesel Murah Mengatasi Polusi dan Kelangkaan BBM. Jakarta: PT. Agromedia Pustaka, 2006.

[6] M. Fadhlullah, S. N. B. Widiyanto, and E. Restiawaty, "The potential of nyamplung (Calophyllum inophyllum L.) seed oil as biodiesel feedstock: Effect of seed moisture content and particle size on oil yield," Energy Procedia, vol. 68, pp. 177-185, 2015, doi: 10.1016/j.egypro.2015.03.246.

[7] D. Hasahatan, J. Sunaryo, and L. N. Komariah, "Pengaruh Ratio H2SO4 dan Waktu Reaksi Terhadap Kuantitas dan Kualitas Biodiesel dari Minyak Jarak Pagar," J. Tek. Kim., vol. 2, no. 18, pp. 26-36, 2012.

[8] A. Wuranto, Motor Diesel Putaran Tinggi. Jakarta: Pradnya Paramita, 1976. 